\title{
Effect of Different Level of Sulphur and Zinc on Soil Health and Yield of Blackgram (Vigna mungo L.) Var. Barkha
}

\author{
Ajay Kumar ${ }^{1 *}$, Narendra Swaroop ${ }^{2}$, Arun Alfred David ${ }^{3}$ and Tarence Thomas ${ }^{4}$ \\ Department of Soil Science and Agricultural Chemistry, Naini Agricultural Institute, \\ Sam Higginbottom University of Agriculture, Technology and Sciences, \\ Prayagraj - 211 007, U.P. India \\ *Corresponding author
}

\section{A B S T R A C T}

\begin{tabular}{l} 
Key w o r d s \\
Blackgram, \\
Sulphur, Zinc, \\
Sulphur, Soil \\
health, etc. \\
\hline Article Info \\
\hline $\begin{array}{l}\text { Accepted: } \\
15 \text { July } 2020 \\
\text { Available Online: } \\
\text { 10 August } 2020\end{array}$ \\
\hline
\end{tabular}

To improve the soil quality, production, productivity and maximizing profit with higher economic returns through application levels of zinc and sulphur. Factorial randomized block design fallowed here with 9 treatment combinations replicated 3 times. Recommended dose of fertilizers i.e. nitrogen, phosphorus and potassium, was applied @ 20:40:20 kg ha ${ }^{-1}$ as urea (46\% $\mathrm{N})$, single super phosphate $\left(16 \% \mathrm{P}_{2} \mathrm{O}_{5}\right)$, muriate of potash $\left(60 \% \mathrm{~K}_{2} \mathrm{O}\right)$ and zinc sulphate $(33 \%$ $\mathrm{Zn}$ ). Application levels of sulphur 0,15 and $30 \mathrm{~kg} \mathrm{ha}^{-1}$ and zinc $0,1.5$ and $3.0 \mathrm{~kg} \mathrm{ha}^{-1}$ at $5 \mathrm{~cm}$ depth in furrows, before seed sowing was done with spacing of $30 \times 10 \mathrm{~cm}$. The accumulative mean of low soil pH (6.85) by $\mathrm{T}_{9}$ - (Zinc@100\%+Sulphur@100\%), electrical conductivity $\left(0.22 \mathrm{dS} \mathrm{\textrm {m } ^ { - 1 } )}\right.$ by $\mathrm{T}_{6}$ - (Zinc@50\% + Sulphur@100\%), particle density $\left(2.64 \mathrm{mg}^{-3}\right)$ by $\mathrm{T}_{5}$ (Zinc@50\%+Sulphur@50\%) and bulk density $\left(1.16 \mathrm{mg}^{-3}\right.$ ) by $\mathrm{T}_{4}$ - (Zinc@50\%+Sulphur@0\%), the higher available nitrogen $\left(273.67 \mathrm{~kg} \mathrm{ha}^{-1}\right.$ ) by $\mathrm{T}_{9}$ - (Zinc@100\% + Sulphur@100\%), available phosphorus (16.49) by $\mathrm{T}_{8}$ - (Zinc@100\% + Sulphur@50\%), available potassium (128.34) by $\mathrm{T}_{9}$ - (Zinc@100\% + Sulphur@100\%), available zinc (1.30) by T $\mathrm{T}_{9}$ (Zinc@ 100\% + Sulphur@100\%) and available sulphur (19.83) by T - (Zinc@100\%+Sulphur@100\%). The combined application of zinc and sulphur along with control, has led to improvement in soil health potential, nutrient availability and yield sustenance under Black gram crop cultivation in which found that the treatment $\left(\mathrm{T}_{9}\right)$ consisting of zinc $(100 \%)+$ sulphur $(100 \%)$ give best result among other treatments.

\section{Introduction}

Pulses are the main source of dietary protein particularly for vegetarians and contribute about $14 \%$ of total protein of an average Indian diet. Pulses covers an area of about 23.63 million hectares with an annual production of 14.76 million tonnes and productivity of $708 \mathrm{~kg} / \mathrm{ha}$ in our country
(GOI, 2011-12). Production of pulses in the country is far below the requirement to meet even the minimum level per capita consumption. The per capita availability in pulses is dwindling fast from $70.0 \mathrm{~g}$ in 1959 to $33.0 \mathrm{~g}$ in 2008 as against the minimum requirement of $84 \mathrm{~g}$ per capita per day as prescribed by ICMR which is causing malnutrition among the growing people 
(Anonymous, 2007). Hence, it is necessary for agricultural scientists to evolve strategy of increasing production and productivity of pulses to meet out the protein requirement of increasing population of the country.

Pulses are grown globally covering large dimension of about 70.50 million hectares in area with a total production of 57.27 million tonnes. Among different pulse producing countries, India ranks first having $29.96 \%$ of the total pulse acreage (2003-2004) though it contributes only $22.52 \%$ of the global pulse production. Over a dozen pulse crops are grown in the country and among these, Chickpea (Chana), Pigeon pea (Arhar), Mungbean (Moong) and Urdbean (Urd) are the most important, contributing total $86.00 \%$ (45.00\% of chickpea, $20.00 \%$ of pigeon pea, $10.00 \%$ of mungbean and $11.00 \%$ of urdbean) of the total pulses production (http://www.iipr.res.in/pe/introduction.asp).

Available sulphur in soils of Jammu region ranges between 2.42 and $5.1 \mathrm{mg} \mathrm{kg}^{-1}$, which is below the critical limit (Kour et al., 2010). In fact, sulphur is the second most important plant nutrient after phosphorus for legume crops. Sulphur interacts with phosphorus as phosphate ion is more strongly bound than sulphate (Hegde and Murthy, 2005).

Black gram [Vigna mungo (L.) Hepper] is one of the important pulse crops grown throughout India. It is a protein rich (25\%) food containing almost three times that of cereals, thus, it is a major source of protein to vegetarian populace. In Jammu and Kashmir, the total area under legume crops is 28.7 thousand hectares with an average productivity of $584 \mathrm{~kg} \mathrm{ha}^{-1}$, which is well below the national level of productivity- 905 $\mathrm{kg} \mathrm{ha}^{-1}$ (Anonymous, 2016).

In India, Andhra Pradesh occupied 555 thousand hectares (18 percent) of area and the largest producer of Black gram accounting for 30 percent (390 thousand tonnes) of the total production, during 2000-2001 in country, followed by Maharashtra, 574 thousand hectares (19 percent) with production 205 thousand tonnes (16 percent). The area under Black gram in Uttar Pradesh was 385 thousand hectares (13 percent) with production 163 thousand tonnes (13 percent), whereas in Tamil Nadu, the area and production was 276 thousand hectares (9 percent) and 127 thousand tonnes (10 percent) respectively. Similarly, in Madhya Pradesh, the area under the crop was 420 thousand hectares (14 percent) with the production of 106 thousand tonnes ( 8 percent). These five major states together contribute about 73 percent of total area and 76 percent of total production, under the Black gram, during the said period. However, in case of productivity, Sikkim stood first (737 $\left.\mathrm{Kgha}^{-1}\right)$, followed by Andhra Pradesh (703 kg ha ${ }^{-1}$ ), West Bengal (522 $\mathrm{Kgha}^{-1}$ ), Punjab (485 $\mathrm{Kgha}^{-1}$ ), Tamil Nadu (462 Kgha ${ }^{-1}$ ), Uttar Pradesh (423 kgha 1), Maharashtra (357 $\mathrm{kgha}^{-1}$ ) and Madhya Pradesh (252 $\left.\mathrm{kgha}^{-1}\right)$ during the period 20002001 (Directorate of Pulses Development, Bhopal).

Blackgram (Vigna mungo L.) is one of the major rainy season pulse crop of India. Urdbean or Black gram is a native of India and originated from Phaseolus sublobatus a wild plant. In India Black gram is very popularly grown in Maharashtra, Andhra Pradesh, Uttar Pradesh, Madhya Pradesh, Tamilnadu, Bihar. Among these black gram or urd (Vigna mungo L.) is pulse crop of many Asian countries and it belongs to tribe phaseolus family leguminoseae.

Sulphur is one of the essential secondary nutrients required for proper plant growth. Its significance is more pronounced in pulse crops, which are deficient in sulphur containing amino acid viz, methionine and 
cysteine. In recent years, introduction of high yielding varieties under intensive cropping systems coupled with use of sulphur free fertilizers viz, urea and diammonium phosphate and progressive decline in the use of organic manures/compost, has led to widespread deficiency of sulphur in soils. The recent statistics showed that sulphur deficiency is pronounced in 87 districts (Ali and Kumar, 2005).

Sulphur is essential for synthesis of proteins, vitamins and S-containing essential amino acids and is also associated with nitrogen metabolism. Sulphur improves both yield and quality of crops. Deficiency of sulphur is increasing due to continuous use of $\mathrm{S}$ - free fertilizers and increasing cropping intensity with high yielding cultivars and is more conspicuous in coarse textured soils low in organic matter (Sipai et al., 2016).

Sulphur containing amino acids like cysteine, cysteine and methionine and promotes nodulation in legumes, also helps in increasing protein percent in legumes and oil percent in oilseeds and involved in the formation of chlorophyll that permits photosynthesis (Patel et al., 2012).

This might be due to known role of sulphur in stimulation of cell division, photosynthetic process as well as formation of chlorophyll. It also promotes the root nodules in legumes, which cause the more Sulphur available during vegetative growth period and development of plant occurs (Yadav et al., 2004).

Zinc in plants required for biosynthesis of hormone. They recommended combined application of soil and foliar when high concentration of grain $\mathrm{Zn}$ is aimed along with high grain yield. Alternatively, sowing $\mathrm{Zn}$ enriched seeds together with foliar application of $\mathrm{Zn}$ is also an effective way to improve both yield and grain $\mathrm{Zn}$ concentration. The micro nutrients including $\mathrm{Zn}$ and $\mathrm{B}$ are the most important nutrients to maintain proper and optimal plant growth. The presence of $\mathrm{Zn}$ and $B$ in the soil helps plant to uptake NPK properly and in adequate amount to maintain crop plant growth and production. The application of $\mathrm{Zn}$ and $\mathrm{B}$ in the intercropping of maize with legumes helps to improve soil nitrogen availability to plants. The presence of $\mathrm{Zn}$ and B in soil improved the soil fertility. $\mathrm{Zn}$ is also involved in the activation of various metabolic enzymes in the roots and plant body (Shojaei and Makariian, 2015).

\section{Materials and Methods}

The investigation on Effect of Different level of Sulphur and Zinc on Soil Health and Yield of Blackgram (Vigna mungo L.) Var. Barkha comprise of a field experiment which was carried out at the Soil Science Central Research Farm, Sam Higginbottom University of Agriculture, Technology and Sciences, Prayagraj during kharif season 2019-20. The details about the experiment site, soil and climate is described in this chapter together with the experimental design, layout plan, culture practice, particulars of treatments, planting material and techniques employed for the parameters. It is located at $25^{\circ} 58^{\prime}$ North latitude and $81^{\circ} 52^{\prime}$ East longitude with an altitude of 98 meter above mean sea level. The area of Prayagraj district comes under subtropical belt in the South east of Uttar Pradesh, which experience extremely hot summer and fairly cold winter. The maximum temperature of the location reaches up to $46^{\circ} \mathrm{C}-48^{0} \mathrm{C}$ and seldom falls as low as $4^{0} \mathrm{C}-5^{0} \mathrm{C}$. The relative humidity ranged between 20 to 94 percent. The average rainfall in this area is around $1100 \mathrm{~mm}$ annually.

The treatment consisted of nine combination of inorganic source of fertilizers $\mathrm{T}_{1}\left(\mathrm{Zn}_{0}+\mathrm{S}_{0}\right)$ 
control, $\mathrm{T}_{2}\left(\mathrm{Zn}_{0}+\mathrm{S}_{15}\right), \mathrm{T}_{3}\left(\mathrm{Zn}_{0}+\mathrm{S}_{30}\right), \mathrm{T}_{4}$ $\left(\mathrm{Zn}_{1.5}+\mathrm{S}_{0}\right), \mathrm{T}_{5}\left(\mathrm{Zn}_{1.5}+\mathrm{S}_{15}\right), \mathrm{T}_{6}\left(\mathrm{Zn}_{1.5}+\mathrm{S}_{30}\right)$, $\mathrm{T}_{7}\left(\mathrm{Zn}_{3}+\mathrm{S}_{0}\right), \mathrm{T}_{8}\left(\mathrm{Zn}_{3}+\mathrm{S}_{15}\right), \mathrm{T}_{9}\left(\mathrm{Zn}_{3}+\mathrm{S}_{30}\right)$. The trial was laid out in a factorial randomized block design with three replication; plot size was $2 \times 2 \mathrm{~m}$ for crop seed rate $15-20 \mathrm{~kg} \mathrm{ha}^{-1}$ (Vigna mungo L.) $\mathrm{Cv}$. Barkha. Barkha RBU-38 is a variety of Black gram, having a source of RAU, Bansawara that were released/notified in the year 1999, into the area of adoption zone in the state of Madhya pradesh, Maharastra and central part of Rajasthan which is having yield area 12.0 (Q ha ${ }^{-1}$ ) with 75 days of time period for maturity that have remarks as bold seeded and resistant to Crecospora leaf spot disease. (dpd.gov.in/VARIETIES). The source of sulphur and zinc were SSP, $\mathrm{ZnSO}_{4}$, respectively. Basal dose of fertilizer was applied in respective plots according to treatment allocation unfurrows opened by about $5 \mathrm{~cm}$. All the agronomic practices were carried out uniformly to raise the crop. Soil samples were collected from the soil $0-15 \mathrm{~cm}$ depth and kept in an oven at $105^{\circ} \mathrm{C}$ for $48 \mathrm{hrs}$ for drying, then pass through $2 \mathrm{~mm}$ sieve after that soils were analysis by using standard procedures as described for $\mathrm{pH}$ 1:2 (m/v)
(Jackson 1958), electrical conductivity $\left(\mathrm{dS} \mathrm{m}{ }^{-1}\right.$ ) (Wilcox 1950), organic carbon \% (Walkley and Black 1947), available nitrogen $\mathrm{kg} \mathrm{ha}^{-1}$ (Subbiah and Asija 1956), phosphorus $\mathrm{kg} \mathrm{ha}^{-1}$ (Olsen et al., 1954) and potassium kg $\mathrm{ha}^{-1}$ (Toth and Prince 1949). The physicoChemical properties at the start of experiment are presented in Table 1 and 2, respectively.

\section{Results and Discussion}

\section{Physico-chemical properties of soil after post-harvest}

The result given in table 3: indicate some of the important parameter on physical properties on black gram crop. Inorganic fertilizers in conjunction on bulk density, particle density and pore space to be significant. The bulk density $\left(1.16 \mathrm{Mg} \mathrm{m}^{-3}\right)$, Particle density $\left(2.64 \mathrm{Mg} \mathrm{m}^{-3}\right)$, and pore space $(56.39 \%)$ of post-harvest soil was recorded. The similar findings were also reported byKumar et al., (2015). The slight decreased in bulk density pore space and increased in particle density may be due to tillage operations and plant growth.

Table.1 Physical properties of soil (pre- sowing)

\begin{tabular}{|l|c|c|}
\hline \multicolumn{1}{|c|}{ Particulars } & Results & Method employed \\
\hline Sand $(\%)$ & 62.71 & Bouyoucous (1927) \\
\hline Silt $(\%)$ & 23.10 & \\
\hline Clay (\%) & 14.19 & \\
\hline Textural class & Sandy loam & \\
\hline Bulk density $\left(\mathrm{Mg} \mathrm{m}^{-3}\right)$ & 1.19 & Black (1965) \\
\hline Particle density $\left(\mathrm{Mg} \mathrm{m}^{-3}\right)$ & 2.64 & Black (1965) \\
\hline Pore space $(\%)$ & $54.92 \%$ & Black (1965) \\
\hline Water holding capacity $(\%)$ & 51.36 & Black (1965) \\
\hline
\end{tabular}


Table.2 Chemical properties of soil (pre-sowing)

\begin{tabular}{|l|c|l|}
\hline \multicolumn{1}{|c|}{ Particulars } & Results & \multicolumn{1}{c|}{ Method employed } \\
\hline Soil EC $\left(\mathrm{dS} \mathrm{m} \mathrm{m}^{-1}\right)$ & 0.22 & Wilcox (1950) \\
\hline Soil pH & 7.21 & Jackson (1958) \\
\hline Organic Carbon $(\%)$ & 0.36 & Walkley and Black (1947) \\
\hline Available Nitrogen $\left(\mathrm{kg} \mathrm{ha}^{-1}\right)$ & 272.18 & Subbiah and Asija (1956) \\
\hline Available Phosphorus $\left(\mathrm{kg} \mathrm{ha}^{-1}\right)$ & 17.29 & Olsen et al., (1954) \\
\hline Available Potassium $\left(\mathrm{kg} \mathrm{ha}^{-1}\right)$ & 125.68 & Toth and Prince (,1949) \\
\hline Available Sulphur $\left(\mathrm{kg} \mathrm{ha}^{-1}\right)$ & 25.57 & Bardsley and Lancaster (1960) \\
\hline Available Zinc $\left(\mathrm{mg} \mathrm{kg}^{-1}\right)$ & 1.25 & Lindsay and Norvell (1969) \\
\hline
\end{tabular}

Table.3 Interaction effect of different levels of Sulphur and Zinc of soils physical after harvest of Black gram

\begin{tabular}{|c|c|c|c|c|}
\hline $\begin{array}{l}\text { Treatment } \\
\text { Combination }\end{array}$ & BD $\left(\mathrm{Mg} \mathrm{m}^{-3}\right)$ & PD $\left(\mathrm{Mg} \mathrm{m}^{-3}\right)$ & Pore space (\%) & $\begin{array}{l}\text { Water holding } \\
\text { capacity }(\%)\end{array}$ \\
\hline $\mathbf{T}_{\mathbf{1}}\left(\mathbf{Z n}_{0} \mathbf{S}_{\mathbf{0}}\right)$ & 1.20 & 2.66 & 54.88 & 48.20 \\
\hline $\mathbf{T}_{2}\left(\mathbf{Z n}_{0} \mathrm{~S}_{1}\right)$ & 1.17 & 2.66 & 56.01 & 55.30 \\
\hline $\mathbf{T}_{3}\left(\mathbf{Z n}_{0} \mathbf{S}_{2}\right)$ & 1.17 & 2.65 & 55.84 & 56.54 \\
\hline $\mathbf{T}_{4}\left(\mathbf{Z n}_{1} \mathbf{S}_{0}\right)$ & 1.16 & 2.66 & 56.39 & 53.78 \\
\hline $\mathbf{T}_{5}\left(\mathbf{Z n}_{1} \mathbf{S}_{1}\right)$ & 1.18 & 2.64 & 55.30 & 51.77 \\
\hline $\mathbf{T}_{6}\left(\mathbf{Z n}_{1} \mathbf{S}_{2}\right)$ & 1.18 & 2.66 & 55.63 & 56.64 \\
\hline $\mathbf{T}_{7}\left(\mathbf{Z n}_{2} \mathbf{S}_{\mathbf{0}}\right)$ & 1.19 & 2.67 & 55.43 & 54.42 \\
\hline $\mathbf{T}_{8}\left(\mathbf{Z n}_{2} \mathbf{S}_{1}\right)$ & 1.17 & 2.66 & 56.01 & 50.68 \\
\hline$T_{9}\left(Z_{2} S_{2}\right)$ & 1.18 & 2.66 & 55.63 & 58.38 \\
\hline F- test & NS & NS & NS & NS \\
\hline S. Em ( $( \pm)$ & 0.02 & 0.02 & 0.70 & 2.34 \\
\hline C.D. at 5\% & 0.05 & 0.07 & 2.09 & 7.02 \\
\hline
\end{tabular}

Table.4 Interaction effect of different levels of Sulphur and Zinc of soil chemical properties after harvest Blackgram

\begin{tabular}{|c|c|c|c|c|c|c|c|c|}
\hline $\begin{array}{c}\text { Treatment } \\
\text { Combination }\end{array}$ & pH 1:2 (w/v) & $\begin{array}{c}\mathbf{E C} \\
\left(\mathbf{d S m}^{-1}\right)\end{array}$ & $\begin{array}{l}\text { O. C. } \\
(\%)\end{array}$ & $\begin{array}{c}\mathbf{N} \\
\left(\mathrm{kg} \mathrm{ha}^{-1}\right)\end{array}$ & $\begin{array}{c}\mathbf{P}_{2} \mathrm{O}_{5}(\mathbf{k g} \\
\left.\mathrm{ha}^{-1}\right)\end{array}$ & $\begin{array}{c}\mathbf{K}_{2} \mathbf{O} \\
\left(\mathrm{kg} \mathrm{ha}^{-1}\right)\end{array}$ & $\begin{array}{c}\text { Sulphur } \\
\text { (ppm) }\end{array}$ & $\begin{array}{c}\text { Zinc } \\
\left(\mathrm{mg} \mathrm{kg}^{-1}\right)\end{array}$ \\
\hline $\mathbf{T}_{1}\left(\mathbf{Z n}_{0} \mathbf{S}_{0}\right)$ & 7.22 & 0.25 & 0.31 & 241.67 & 14.36 & 117.61 & 13.06 & 1.21 \\
\hline $\mathbf{T}_{2}\left(\mathbf{Z n}_{0} \mathbf{S}_{1}\right)$ & 7.10 & 0.27 & 0.35 & 254.88 & 14.47 & 118.18 & 17.47 & 1.19 \\
\hline $\mathbf{T}_{3}\left(\mathbf{Z n}_{0} \mathbf{S}_{2}\right)$ & 6.91 & 0.29 & 0.41 & 261.67 & 15.66 & 120.46 & 14.34 & 1.20 \\
\hline $\mathbf{T}_{4}\left(\mathbf{Z n}_{1} \mathbf{S}_{0}\right)$ & 7.00 & 0.26 & 0.36 & 245.33 & 14.98 & 122.98 & 13.65 & 1.23 \\
\hline $\mathbf{T}_{5}\left(\mathbf{Z n}_{1} \mathbf{S}_{1}\right)$ & 7.16 & 0.24 & 0.38 & 262.33 & 15.40 & 120.77 & 18.69 & 1.25 \\
\hline $\mathbf{T}_{6}\left(\mathbf{Z n}_{1} \mathbf{S}_{2}\right)$ & 7.12 & 0.22 & 0.34 & 260.67 & 16.20 & 118.41 & 15.70 & 1.24 \\
\hline $\mathbf{T}_{7}\left(\mathbf{Z n}_{2} \mathbf{S}_{\mathbf{0}}\right)$ & 7.05 & 0.24 & 0.42 & 258.33 & 16.39 & 124.74 & 16.46 & 1.27 \\
\hline $\mathbf{T}_{8}\left(\mathbf{Z n}_{2} \mathbf{S}_{1}\right)$ & 6.97 & 0.23 & 0.43 & 271.67 & 16.49 & 125.78 & 19.57 & 1.28 \\
\hline $\mathbf{T}_{9}\left(\mathbf{Z n}_{2} \mathbf{S}_{2}\right)$ & 6.85 & 0.24 & 0.44 & 273.67 & 16.38 & 128.34 & 19.83 & 1.30 \\
\hline F- test & $\mathrm{S}$ & $\mathrm{S}$ & $\mathrm{S}$ & S & $\mathrm{S}$ & S & $\mathrm{S}$ & $\mathrm{S}$ \\
\hline S. Em ( $( \pm)$ & 0.04 & 0.01 & 0.02 & 6.00 & 0.43 & 1.35 & 0.15 & 0.01 \\
\hline C. D. at $5 \%$ & 0.12 & 0.04 & 0.06 & 17.98 & 1.30 & 4.05 & 0.44 & 0.03 \\
\hline
\end{tabular}


The results in given table 4: indicate some of the important parameter of chemical

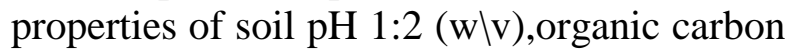
$(\%)$, available nitrogen $\left(\mathrm{kg} \mathrm{ha}^{-1}\right)$, phosphorus $\left(\mathrm{kg} \mathrm{ha}^{-1}\right)$ and potassium $\left(\mathrm{kg} \mathrm{ha}^{-1}\right)$ was found significant. Electrical conductivity $(0.24 \mathrm{dsm}$ ${ }^{1}$ ), organic carbon $(0.44 \%)$, available nitrogen (273.67 kg ha' $\left.{ }^{-1}\right)$, phosphorus (16.49 $\left.\mathrm{kg} \mathrm{ha}^{-1}\right)$, and potassium $\left(128.34 \mathrm{~kg} \mathrm{ha}^{-1}\right)$ was recorded and significantly higher as compared to other combination. It was properly due to positive effect of Zinc and Sulphur by increasing the nodulation resulted higher fixation of atmospheric nitrogen and ultimately increased the growth characters. The similar findings were also reported by Abdul et al., (2008). Zinc $\left(1.30 \mathrm{mg} \mathrm{kg}^{-1}\right)$ and Sulphur $(19.83 \mathrm{~kg}$ $\mathrm{ha}^{-1}$ ) was recorded significantly higher as compared to other combination. $\mathrm{Zn}$ deficiency leading to a substantial reduction in grain yield and nutritional quality. The similar findings were reported by Cakmak et $a l .,(1999)$. There was a slight decrease in soil $\mathrm{pH}$ and increase in soil electrical conductivity (dS $\mathrm{m}^{-1}$ ), organic carbon (\%), available nitrogen $\left(\mathrm{kg} \mathrm{ha}^{-1}\right)$, phosphorus $\left(\mathrm{kg} \mathrm{ha}^{-1}\right)$ and potassium $\left(\mathrm{kg} \mathrm{ha}^{-1}\right)$ it may be due to increase in levels of inorganic fertilizer and plant growth, which increase the plant residue into soil.

In conclusion the present investigation, it was apparent that application of Sulphur and Zinc fertilizer. The combined application of Zinc with Sulphur, has led to improvement in soil health potential, nutrient availability and yield sustenance under Blackgram cultivation in which found that the treatment $\left(\mathrm{T}_{9}\right)$ consisting of Zinc (100\%) + Sulphur (100\%) give best result among other treatments.

\section{Acknowledgements}

The authors are grateful to the Vice Chancellor, Departmental Staff \& Head of SSAC, SHUATS, Prayagraj for taking their keen interest and encouragement to carry out the research work.

\section{References}

Abdul Baser, Zanier Shat, Muhammad Naeem, FehanBakht, Hfan ZH (2008). Effect of phos pharos and farm yard manure an agronomic traits of chickpea (Aicer arietinum L) Sarhad Journal of Agriculture. 2008; 24(4):567-572

Anonymous. (2016). Digest of Statistics. Directorate of Economics \& Statistics, J \& K, p. 106

Anonymous, (2007). Hand Book of Agriculture, ICAR, New Delhi, pp 972973

Bardsley, C.E. and Lancaster, J.D. (1960). Determination of reserve sulphur and soluble sulphates in soil. Soil Sci. Soc. Amer. Proc., 24 265- 268

Black CA (1965). Methods of soil analysis vol.2, Am. Soc, Agron. madison, Wisconsin, U.S.A, 1965.

Bouyoucos, G.J. (1927). The hydrometer as a new method for the mechanical analysis of soil. Soil Sci. 23. 343-353

Cakmak I, Kalayci M, Ekiz H, Braun HJ, Yilmaz A (1999). Zinc deficiency as an actual problem in plant and human nutrition in Turkey: a NATO Science for Stability Project. Field Crops Res. 60:175-188

Directorate of Pulses Development: http://dpd.gov.in/contact.htm

Directorate of Pulses Development: http://dpd.gov.in/VARIETIES

GOI, (2012). Submitted by Zonal Project Directorate Kanpur, pp.20-35

Hegde, D. M. and Murthy, I. Y. L. N. (2005). Management of secondary nutrients. Indian Journal of Fertilizer, 1: 93-100

Indian institute of pulses research: http://www.iipr.res.in

Jackson ML. Soil Chemical Analysis. Prentice Hall of India Pvt. Ltd. New 
Delhi.1973;52.

Kour, S., Arora, S., Jalali, V. K. and Mondal, A. K. (2010). Soil sulfur forms in relation to physical and chemical properties of midhill soils of North India. Communications in Soil Science and Plant Analysis, 41:277-289

Kumar Sant Sharma Sunil Prajapati and Omveer Raghuvanshi (2015).Effect of organic manures and Inorganic fertilizers on yield and economics of Green gram production (Vigna radiata L.), Indian Res. J. Genet.\& Biotech 7(1): $152-155$.

Lindsay WL, Norvell WA (1969). Equilibrium relationship of $\mathrm{Zn} 2+$, $\mathrm{Fe} 2+,, \mathrm{Ca} 2+$, and $\mathrm{H}+$ with EDTA and DTPA in soils. Soil Sci. Soc. Amer. Proc, 1969; 35:62-68

Olsen. (1954) Estimation of available Phosphorus in soil by extraction with sodium bicarbonate U. S. Deptt.Agr.Circ., 939

Patel, H. R., Patel, H.F., Maheriya, V.D. and Dodia, I.N. (2012). Response of kharif Greengram (Vigna raditta L. Wilczek) to sulphur and phosphorus Fertilization with and without biofertilizer Application, The bioscan 8(1): 149-152

Shojaei, H. and H. Makarian, (2015). The effect of Nano and Non-Nano Zinc oxide particles foliar application on yield and yield components of
Mungbean (Vigna radiatal.) under drought stress. Iranian journal of field crops research, 12:76

Sipai, A.H., Jat, J.R. and Rathore, B.S. (2016). Effect of phosphorus, sulphur and Biofertilizer on growth, yield and nodulation in mungbean on loamy sand soils of kutch. A Scitechnol journal 51.(1) 51: 56

Subbiah BV, Asija GL.(1956).A rapid procedure for the estimate of Available nitrogen in soil. Current sciences.; 25:259-260

Toth, S.J. and Prince, A. L. (1949) Estimation of cation exchange capacity and exchangeable $\mathrm{Ca}, \mathrm{K}$ and $\mathrm{Na}$ content of soil by flame photometer technique. Soil Sci., 67: 439-445

Walkley, A. and Black, I. A. (1947) Critical examination of rapid method for determining organic carbon in soils, effect of variance in digestion conditions and of inorganic soil constituents. Soil Sci., pp. 632:251.

Wilcox, L. V. (1950) Electrical conductivity Am. water works Assoc. J 42,775-776

Yadav S.S. (2004). Growth and yield of greengram (Vigna radiata L.) as influenced by phosphorus and sulphur fertilization under rainfed condition. Haryana Journal of Agronomy 20(1): $10-12$

\section{How to cite this article:}

Ajay Kumar, Narendra Swaroop, Arun Alfred David and Tarence Thomas. 2020. Effect of Different Level of Sulphur and Zinc on Soil Health and Yield of Blackgram (Vigna mungo L.) Var. Barkha. Int.J.Curr.Microbiol.App.Sci. 9 (08): 1175-1181. doi: https://doi.org/10.20546/ijcmas.2020.908.130 